\title{
Whither America?
}

\author{
Michael Bernhard and Daniel O’Neill
}

\section{The Regime Question in American Politics}

$\square$

ne of the most important scholarly interventions on the global crisis of democracy in the $1960 \mathrm{~s}$ and 1970s was the introductory essay to an ambitious and comprehensive study of the breakdown of democracy. In it, Juan Linz created an original framework for understanding democracy under duress. Democratic breakdown was the product of crisis, which did not necessarily lead to authoritarianism but might also resolve through the reequilibration of democracy. The enduring value of that essay is attested to by its continued publication as a separate slim volume and its place on graduate syllabi to this day (Linz 1978).

Today, the deep divisions in American politics revealed by President Trump's impeachment and subsequent trial are paralleled in the U.S. public as well. For example, a recent Pew study on the attitudes of Americans towards the press showed that the left and right have largely separate sources of trusted news. It also showed that the left trusts a much wider array of sources, whereas on the right only Fox News has the trust of more than $50 \%$ of those polled (Jurkowitz et al. 2020).

We are clearly in the midst of a crisis that will determine the future character of our politics. The issue in the United States is executive power, specifically President Trump's expansive sense of what he is entitled to do under the constitution. The issue raised by the first article of impeachment is his use of the executive branch and its resources to encourage foreign governments to intervene in the U.S. electoral process on his behalf by attacking the perceived frontrunner in the democratic primaries, former vice president Joe Biden. The second article is concerned with obstruction of Congress, specifically the blanket refusal of the administration to cooperate in congressional efforts to exercise legislative oversight over the executive branch, thereby threatening to destroy the separation of powers. One wonders what James Madison, or even Alexander Hamilton, would have done when confronted with a president of the United States whose reading of the parameters of executive power under the United States Constitution is, as Trump has repeatedly put it, "I have an Article 2, where I have the right to do whatever I want as president."

Under Linz's framework, when democracy is threatened by crisis, as it is now, it can fail as it did classically in multiple cases in interwar Europe and in bureaucratic authoritarian Latin America. Alternatively, with proactive intervention by democratic actors, democracy can be defended, and the system can be restored to equilibrium. The interwar cases of reequilibration-Czechoslovakia, Finland, and Belgium-largely returned to the status quo ante (Capoccia 2005). The great postwar case of reequilibration-the crisis of the French Fourth Republic in 1958 -included a major reconfiguration of the institutions of democracy with the birth of the Fifth (Suleiman 1994).

Today's situation in the United States and elsewhere is less dichotomous in terms of outcomes. Linz's conceptualization of democratic breakdown is punctuated. It involves critical events that mark a decisive abrogation of the minimal conditions for democracy, like coups, civil wars, putsches, and seizures of power. Today democracy seems to fail less in this wholesale punctuated fashion. Rather it deteriorates, slowly in what contemporary comparative politics has called backsliding (Bermeo 2016; Waldner and Lust 2018). This sometimes leads to authoritarian regime change, but in other cases, just to a deterioration of the quality of democracy.

Are there potential breakdown scenarios for American democracy? Only the possibility of a slow death really exists. Nothing is possible except under the cover of rule of law, making grand gestures unlikely. Nevertheless, Trump's presidency represents a substantial weakening of the horizontal accountability of the legislative branch over the executive. Furthermore, the failure of the Roberts Court to expedite cases concerning the refusal of executive officials to testify in impeachment hearings or of executive agencies to hand over documents (Damante and Gorod 2019), makes the likelihood that the Supreme Court will remedy this situation or act to exercise substantial accountability over the executive seem slim. Indeed, the Trump administration's ability to effectively pack the lower courts means that many of the issues related to executive oversight may never reach the Supreme Court in the first instance. This will leave the House with one 
source to exercise constraint over the executive branch: the power of the purse. However, the politics of budget impasse are dangerous for both the health of the economy and the government's ability to borrow money, and are subject to a tricky and potentially damaging politics of blame. In addition, one person, one vote and majority rule are already under threat at both the federal level and for many state governments because of the manipulation of the voting system (Bernhard and O'Neill 2019). Given these conditions, the American regime under the Trump administration looks less and less like a high-quality democracy and more and more like a low-quality delegative democracy, where only vertical accountability functions periodically, or even a competitive authoritarian regime (O’Donnell 1994; Levitsky and Way 2010).

Nevertheless, the one remaining path to reequilibration lies through the vertical accountability provided by elections, notwithstanding their recent problems. We can already assume that Donald Trump will continue to flaunt the rules in his pursuit of reelection. The Mueller investigations acted as no deterrent, even more so because of Mueller's unwillingness to challenge the 1973 opinion of the Department of Justice's Office of the Legal Counsel that a sitting president could not be indicted for crimes. This opinion was rendered by Richard Nixon's Department of Justice in the midst of the Watergate investigation and has never been ruled on in court. We can assume that Trump's exoneration by the Senate will do nothing to break this pattern. He has already asked the Russians, Ukrainians, and Chinese to interfere in our elections so there is very little reason to believe he will be chastened by the experience of impeachment.

The ultimate outcome of the democratic primaries and who leads the opposition ticket thus assume crucial importance. While the press has talked about the primary contest as a two-level struggle between groups of candidates to win by assuming the mantle of either the progressive or the moderate wing of the party, the differences go beyond policy. It is pretty clear that the major democratic candidates see the outcome of the election as a regime question, and that failure to defeat Donald Trump places American democracy at further and escalating risk. What separates the two wings of the party is the question of how to reequilibrate. For the moderates, Trump himself is the problem, and his replacement by a "normal" president who respects the law and norms of American democracy will go far in repairing the damage. For the progressives, Trump is more of a symptom than a cause and his successor will have to take steps to address the conditions that made him possible in the first place. And for the progressives the touchstone issues are distributive, specifically social and economic inequality, the privileged position of capital, and systematic discrimination on the basis of race and identity.

\section{Whither America?}

The special section in this issue directly addresses the fundamental questions of whether the Trump presidency threatens American democracy and whether the system can reequilibrate after Trump. Our lead article, by Stephen Skowronek and Karen Orren, is the most pessimistic. In "The Adaptability Paradox: Constitutional Resilience and Principles of Good Government in Twenty-First Century America" they argue that faith in the idea that American institutions are sound and that they will be able to recover as they have after past crises is misplaced. They argue that, in the past, post-crisis adjustments involved extra-constitutional institutional developments that relied on the incorporation of previously excluded groups into the system. They conclude that the institutional capacity to do so is now exhausted and that future adaptation under the current framework will be much more difficult than in the past.

The other two articles in our consideration of the future of the United States are influenced by the burgeoning comparative politics literature on populism and are much more optimistic. Frances Lee, in "Populism and the American Party System: Opportunities and Constraints," argues that the U.S. system is less open to populist parties than other democracies but is not immune to populist candidacies. She also argues that the properties of the U.S. party system that obstruct the accumulation of power also make the prospect of an authoritarian populist system change unlikely. Despite the general optimism of her assessment, in a more cautionary note she also discusses how the parties themselves are more vulnerable to populist insurgencies.

In "Populism's Threat to Democracy: Comparative Lessons for the U.S." Kurt Weyland compares the situation in the United States to other countries that have grappled with the threat of populism in Latin America and Europe. He develops a theory of what has enabled populist parties to dismantle democratic institutions-a combination of weak institutions, and acute but resolvable crises or extraordinary electoral bonanzas. Given the strength of U.S. institutions and their proclivity to disperse power, as well as the strength of civil society, the re-energization of the Democratic Party political opposition, and Trump's unpopularity, Weyland concludes that the structural conditions for a populist regression are simply not present in the United States.

\section{Other Content}

We have a rich diversity of truly excellent articles in this issue. The first of these, "Populism and Backlashes against International Courts" by Erik Voeten, connects with Lee and Weyland in our ongoing exploration of the impact of populism on contemporary politics. Voeten explores why populist rulers attack decisions by international courts that displease them rather than simply accepting or ignoring 
them like many other incumbents. His answer emerges in the realm of domestic politics where he argues that this is a product of the proclivity of populists to try to undermine the kind of horizontal accountability that courts of any kind, whether international or domestic, can impose on their ability to pursue unchecked majoritarian power.

In "Institutions, Ideologies, and Comparative Political Theory," Joshua Simon argues for bringing both the methods of comparative politics and Marxist ideology critique to the study of comparative political theory. Doing so, Simon contends, enables important insights into how political thinking varies across chronological, geographical, and cultural contexts. For Simon, this can serve as the foundation for both deconstructive critiques, which reveal the partial interests of putatively universal political ideas, or reconstructive critiques, which identify particular thinkers or traditions of political thought that can offer compelling critical perspectives on existing political institutions.

In "Expressive Voting in Autocracies: A Theory of Non-Economic Participation with Evidence from Cameroon" Natalie Wenzell Letsa explores the reasons why citizens of electoral authoritarian regimes vote. She challenges the long-standing literature on economic voting and finds that in Cameroon non-economic motivations like a sense of duty or a commitment to democracy explains why more people vote. The implications of such findings are important for the study of electoral autocracies and why they sometimes persist despite long bouts of economic stagnation.

We have two articles in this issue that explore issues of critical concern in the historical rise of democracy. Kevin Narizny challenges the dominant narrative on the English "Glorious" Revolution as a landmark case of political compromise and institutional crafting that solved longstanding and perilous coordination problems between elite factions in England. Instead, in "The Political-Economic Foundations of Representative Government," he looks at structural change in the agrarian capitalist economy and the rise of new actors who pushed for the creation of representative government to protect their new private interests.

Moving across the Atlantic, David Alexander Bateman examines the issue of the African American franchise in free states prior to the American Civil War. In "Partisan Polarization on Black Suffrage, 1785-1868" he looks at the heated struggles over disenfranchisement in the early post-independence period and the protracted struggle to secure voting rights in the run-up to the Civil War. Using new sources of both qualitative and quantitative data at the state level, Bateman discovers patterns of party-based polarization and explores one of the earliest struggles that pit white supremacy against biracial efforts to establish national unity through struggles for black suffrage.
Max Gallien's "Informal Institutions and the Regulation of Smuggling in North Africa" is testimony to how certain questions can only be adequately studied and answered through the use of in-depth ethnographic methods and careful, intensive fieldwork. While we often think of smuggling as informal activity, Gallien uncovers networks of collaboration between smugglers and state officials, and a maze of informal institutions and practices that turn illegal activity into a commonplace facet of everyday life and an important part of the economy. The implications of his findings are wide-ranging for how we study formal and informal institutions, the problem of state capacity in the developing world, and the role of black and gray markets in economics and politics.

We continue our efforts to publish innovative methodological work with Rana B. Khoury's "Hard-to-Survey Populations and Respondent-Driven Sampling: Expanding the Political Science Toolbox." In this piece she addresses how to measure the attitudes of difficult-tosurvey populations, such as those engaged in collective action or wishing to keep their identities hidden (refugees, oligarchs, radical political activists, and others who are hard to reach). She applies the tool of respondent driven sampling (RDS), which uses the establishment of trust between the researcher and the subjects of research to survey such populations, and then thinks in innovative ways about how to assess the representativeness of the group sampled. She performs such an analysis on a group of activist refugees from Syria and demonstrates that the knowledge yielded by RDS improves what we can say about the beliefs of such populations.

The last item in this issue is a Reflections piece that introduces a new and innovative dataset to the discipline. In "The Dynamics of Racial Resentment across the 50 US States" Candis Watts Smith, Rebecca Jane Kreitzer, and Feiya Suo present their estimates of racial resentment across the fifty states from 1988 to 2016. They are able to accomplish this by linking census and public opinion data using multilevel regression techniques and post-stratification weighting. The data will be of great use to scholars who see racial animus as an important explanatory factor in many aspects of American politics. Contrary to dominant narratives about racism in the United States, the data shows great variation across states and across regions, while it is ambiguous on the question about whether racial resentment is lower now than it has been historically.

\section{New Developments at the Journal}

The next two issues are shaping up nicely. The next (18:3) will be a special issue that looks at the role that violence plays in a range of contemporary political phenomena. And following that (in 18:4) we will have a special section of articles devoted to issues of women and politics and will be publishing an assessment of the work of the "Qualitative Transparency Deliberations" by 
its authors. For those of you who cannot wait, most of this material is already up on FirstView (https:// www.cambridge.org/core/journals/perspectives-on-politics/ firstview) or will be available there soon.

In the past all reviewers for Perspectives on Politics had access to the reports provided by other readers and we readily shared our decisions on manuscripts with those who provided the reviews that helped us make those decisions. We recently began to send all reviewers notification on the final disposition of submissions they reviewed (accept or reject) and a reminder of where they can access the other reviews. This seems like a good moment to thank all those who have done manuscript reviews for the journal over the past two-and-half years. Without your work the quality of the articles would not have been as high, and our job would have been impossible. We would also like to take this opportunity thank all of you who have written book reviews since we assumed editorship. Without your selflessness we could not review between 350 and 400 books a year and fulfill our mission as the book review of record for the American Political Science Association.

\section{References}

Bermeo, Nancy. 2016. "On Democratic Backsliding." Journal of Democracy 27(1): 5-19.

Bernhard, Michael and Daniel O’Neill. 2019. “Trump: Causes and Consequences." Perspectives on Politics 17(2): 317-24.
Capoccia, Giovanni. 2005. Defending Democracy: Reactions to Extremism in Interwar Europe. Baltimore, MD: Johns Hopkins University Press.

Damante, Becca and Briane Gorod. 2019. "The Supreme Court Has the Power to Expedite Impeachment Cases." Slate. Retrieved January 25, 2019 (https://slate.com/ news-and-politics/2019/12/supreme-court-donaldtrump-impeachment-cases.html).

Jurkowitz, Mark, Amy Mitchell, Elisa Shearer, and Mason Walker. 2020. U.S. Media Polarization and the 2020 Elections: A Nation Divided. Washington, DC: Pew Research Center.

Levitsky, Steven and Lucan Way, 2010. Competitive Authoritarianism: Hybrid Regimes after the Cold War. Cambridge: Cambridge University Press.

Linz, Juan. 1978. The Breakdown of Democratic Regimes: Crisis, Breakdown and Reequilibration. An Introduction. Baltimore, MD: Johns Hopkins University Press. O’Donell, Guillermo. 1994. "Delegative Democracy." Journal of Democracy 5(1): 55-69.

Suleiman, Ezra N. 1994. "Presidentialism and Political Stability in France." In The Failure of Presidential Democracy: Comparative Perspectives, eds. Linz Juan and Arturo Valenzuela. Baltimore, MD: Johns Hopkins University Press.

Waldner, David and Ellen Lust. 2018. "Unwelcome Change: Coming to Terms with Democratic Backsliding." Annual Review of Political Science 21: 93-113. 


\section{Statement of Mission and Procedures}

Perspectives on Politics seeks to provide a space for broad and synthetic discussion within the political science profession and between the profession and the broader scholarly and reading publics. Such discussion necessarily draws on and contributes to the scholarship published in the more specialized journals that dominate our discipline. At the same time, Perspectives seeks to promote a complementary form of broad public discussion and synergistic understanding within the profession that isessential toadvancing scholarship and promoting academic community.

Perspectives seeks to nurture a political science public sphere, publicizing important scholarly topics, ideas, and innovations, linking scholarly authors and readers, and promoting broad reflexive discussion among political scientists about the work that we do and why this work matters.

Perspectives publishes work in a number of formats that mirror the ways that political scientists actually write:

Research articles: As a top-tier journal of political science, Perspectives accepts scholarly research article submissions and publishes the very best submissions that make it through our double-blind system of peer review and revision. The only thing that differentiates Perspectives research articles from other peer-reviewed articles at top journals is that we focus our attention only on work that in some way bridges subfield and methodological divides, and tries to address a broad readership of political scientists about matters of consequence. This typically means that the excellent articles we publish have been extensively revised in sustained dialogue with the editors to address not simply questions of scholarship but questions of intellectual breadth and readability.

"Reflections" are more reflexive, provocative, or programmatic essays that address important political science questions in interesting ways but are not necessarily as systematic and focused as research articles. These essays often originate as research article submissions, though sometimes they derive from proposals developed in consultation with the editor in chief. Unlike research articles, these essays are not evaluated according to a strict, doubleblind peer review process. But they are typically vetted informally with editorial board members or other colleagues, and they are always subjected to critical assessment and careful line-editing by the editor and editorial staff.

Scholarly symposia, critical book dialogues, book review essays, and conventional book reviews are developed and commissioned by the Associate and Book Review Editor, based on authorial queries and ideas, editorial board suggestions, and staff conversations.

Everything published in Perspectives is carefully vetted and edited. Given our distinctive mission, we work hard to use our range of formats to organize interesting conversations about important issues and events, and to call attention to certain broad themes beyond our profession's normal subfield categories.

For further details on writing formats and submission guidelines, see our website at http://www.apsanet.org/ perspectives/ 